\title{
Development of a Novel Carrot-based Synbiotic Beverage using Lactobacillus casei 431 $^{\circledR}$
}

\author{
A. D. P. S. Alwis ${ }^{1}$, O. D. A. N. Perera ${ }^{1}$ and H. L. D. Weerahewa ${ }^{2}$ \\ Received : $22^{\text {th }}$ October 2015 / Accepted : $14^{\text {th }}$ January 2016
}

\begin{abstract}
Lactobaccilus casei $431^{\circledR}$ is a probiotic microorganism, intentionally introduced into fruits and vegetable juices due to its great activity and survivability. Carrot is comprised with many functional food components such as vitamins ( $A, C, D$, and $K$ ) minerals (calcium, potassium, phosphorus, sodium, and iron) and prebiotic compounds (Fructo-oligosaccharide (FOS) and inulin). This research was undertaken to determine the suitability of carrot as raw material for production of synbiotic beverage. The beverage was formulated by incorporating L. casei $431^{\circledR}$ into carrot juice and fermenting for 0,2 or 4 h at $37^{\circ} \mathrm{C}$. Viable counts of L. casei $431^{\circledR}$, pH, total soluble solids (oBrix), titratable acidity, crude fiber, sugars and sensory characteristics were investigated weekly for a period of six weeks under refrigerated $\left(5 \pm 1{ }^{\circ} \mathrm{C}\right)$ storage. The beverage fermented for $2 \mathrm{~h}$ yielded the highest consumer acceptability. L. casei $431{ }^{\circledR}$ reached $108 \mathrm{CFU} / \mathrm{mL}$ after $2 \mathrm{~h}$ of fermentation at 37 oC meeting the standards to be considered as a functional food for 6 weeks of storage at $\left(5 \pm 1^{\circ} \mathrm{C}\right)$. The utilization of FOS by L. casei $431^{\circledR}$ was minimized with the addition of sucrose and there was no significant difference $(p \geq 0.05)$ in the amounts of crude fiber during storage. The carrot-based synbiotic fermented beverage could be served as a ready to drink product for 6 weeks under refrigerated storage, meeting the standards (108-1010 CFU/ mL) of a functional drink
\end{abstract}

Keywords: carrot, prebiotics, Lactobacillus casei, $431^{\circledR}$, Probiotics

\section{INTRODUCTION}

In recent years, the consumer demand for functional foods has steadily increased beyond providing basic nutrition due to its ability to reduce the risk of certain health problems including cancer, osteoporosis, and even childhood blindness. Therefore, the products with probiotics and prebiotics show considerable promise for the expansion of the functional food industry.

Recently, researches have reported the evaluation of probiotic and prebiotic supplemented foods, in which fructooligosaccharides, Bifidobacterium and Lactobacillus are those most utilized. Most research has focused on evaluating the addition of probiotics and prebiotics, obtaining a product with a better final quality known as synbiotic food (Evangelista et al., 2012).

Prebiotic oligosaccharides are noncariogenic, non digestible oligosacharides(NDO) and low calorific compounds stimulating the growth and development of gastrointestinal microflora described as probiotic bacteria (Barreteau et al., 2006). Dietary carbohydrates that show prebiotic ability include fructooligosaccharides (FOS), galactooligosaccharides (GOS), polydextrose, resistant starch, 
soyoligosaccharides, xylooligosaccharides, isomaltooligosaccharides, and lactulose (Gibson et al., 2000).

In practice, the most common oligosaccharides are inulin and its hydrolysates and oligofructans. They can be found in chicory, onion, garlic, asparagus, artichoke, leeks, bananas, tomatoes and many other plants (Grajek et al., 2005; Sousa et al., 2011).

Probiotics are defined as selected, viable microbial dietary supplements that, when introduced in sufficient quantities, beneficially affect human organism through their effects in the intestinal tract. Some selected strains of Lactobacillus, Bifidobacterium, Streptococcus, Lactococcus and Saccharomyces have been promoted in food products because of their reputed health benefits. Lactic acid bacteria constitute a diverse group of organisms providing considerable benefits to humans, some as natural inhabitants of the intestinal tract and others as fermentative lactic acid bacteria used in food industry, imparting flavor, texture and possessing preservative properties (Grajek et al., 2005).

Various researchers have discovered the use of different fruits, vegetables and cereals for producing probiotic and synbiotic beverages. The production of synbiotic beverages mostly involved with the products which were already composed of prebiotic compounds.

Some research was based on producing synbiotic beverages using carrot. Carrots contain fructooligosaccarides and inulin as prebiotics and facilitate the growth of two probiotic strains, Lactobacillus rhamnosus and L. bulgaricus (Nazzaro et al., 2008). Carrot is one of the important root vegetables rich in bioactive compounds like carotenoids and dietary fibers with appreciable levels of several other functional components having significant health-promoting properties. The consumption of carrot and its products is increasing steadily due to its recognition as an important source of natural antioxidants having anticancer activity (Sharma et al., 2012).

Recently novel food products produced from functionally valuable commodities have gained an increasing consumer demand due to their excellent health benefits and also for the convenience and their various features that fulfill modern consumer demands. Therefore, the scope of the envisaged research work is to develop nutrient rich shelf stable synbiotic beverage using carrot and evaluate the physicochemical characteristics and the consumer acceptability of the developed product.

\section{MATERIAS AND METHODS}

\section{Beverage preparation}

This research was carried out in the Food Processing Laboratory of the Department of Food Science and Technology, Wayamba University of Sri Lanka. Carrots cv 'New kuroda' were purchased from a local store at Pannala. After being washed thoroughly, carrots were peeled and cut (thickness approx. $0.5 \mathrm{~cm})$ and were blanched in acidified water with citric acid $(2 \mathrm{~g} / \mathrm{kg}$ carrots $)$ at $80^{\circ} \mathrm{C}$ for 6 $\mathrm{min}$. The juice was prepared using a laboratory juice extractor (PANASONIC, Japan) without adding any water to the sample. Coarse particle content was separated gravimetrically by centrifugation of carrot juice at $4000 \mathrm{Xg}$ (model 2-16 K, Germany) for $20 \mathrm{~min}$. The supernatant was transferred to a sterile container. Juice was heated up to $50^{\circ} \mathrm{C}$ and sucrose $(35 \mathrm{~g} / \mathrm{L})$ was added. Carrot juice was homogenized for $3 \mathrm{~min}$ and mixture was pasteurized at $90^{\circ} \mathrm{C}$ for $1 \mathrm{~min}$. At $43^{\circ} \mathrm{C}$, a commercial culture of Lactobacillus casei $431^{\circledast}$ (CHR-HANSON - Denmark) $(0.1 \mathrm{~g} / \mathrm{L})$ was added.

The fermentation of the carrot juice was performed at $37^{\circ} \mathrm{C}$ for $0 \mathrm{~h}, 2 \mathrm{~h}$ and $4 \mathrm{~h}$. The beverage with highest sensory acceptability was selected and stored under refrigerated conditions $\left(5 \pm 1^{\circ} \mathrm{C}\right)$. 


\section{Physico - chemical characteristics}

The $\mathrm{pH}$ of the beverage samples was measured by using a $\mathrm{pH}$ meter (OHAUS- USA). Titratable acidity was determined by titrating $10 \mathrm{~mL}$ of sample against $10 \mathrm{~N} \mathrm{NaOH}$ in the presence of phenolphthalein as an indicator (Sharma, 2006). The total soluble solid content was measured by using a refractometer (ATAGOJapan). The moisture and total solids of samples were determined by drying samples at $105 \pm 1 \mathrm{oC}$ overnight to constant weight using an air convection oven (Memmert-USA). The ash content was measured by ignition of solid materials at $555 \mathrm{oC}$ in an electric muffle furnace (HOBERSAL - Spain). The protein content was determined by the Kjeldhal method. Details of the total solids, ash, and protein content assays were as described by James, 1996. Determination of crude fiber, total sugars, reducing sugars and \% sucrose were determined by using AOAC (2000).

\section{Sensory evaluation}

Sensory evaluation was done using a descriptive test for overall quality (color appearance, taste, flavor, consistency and overall acceptability) of the carrot beverage using a panel of $30 \mathrm{semi}$ trained panelists once in two weeks using a 9 point hedonic scale ( 9 and 1 points showing like extremely and dislike extremely) (Stone and Sidel, 1993). The beverage with highest sensory score was selected and stored under refrigerated conditions $\left(5 \pm 1^{\circ} \mathrm{C}\right)$ for 6 wks.

\section{DPPH radical scavenging activity}

Radical scavenging activity of methanolic carrot extracts against stable DPPH (2, 2-diphenyl-1picrylhydrazyl) was measured using a slightly modified method of Williams et al., 1995 by UV/visible light spectrophotometer (OPTIMA INC- Japan) at $517 \mathrm{~nm}$.

\section{Microbiological analysis}

Viable counts of lactic acid bacteria of the juice were measured by spread plate techniques in triplicate on MRS (De Man et al., 1960) agar (Hi Media - India). $1.0 \mathrm{~mL}$ samples were added to $9.0 \mathrm{~mL}$ of sterile Ringers solution and appropriate dilutions were made (10-1 to 10-5). Subsequently, the spread plating was carried out for each and every dilution. Then plates were incubated in anaerobic systems using AnaeroPack system. The AnaeroPack system requires no catalyst or water, produces no hydrogen, and is oxygen absorbing and carbon dioxide generating.

Colony forming units were enumerated in plates containing 30 to 300 colonies by using a colony counter after $72 \mathrm{~h}$ of incubation at $37 \mathrm{oC}$.

Coliform counts were estimated using MacConkey agar plates incubated at $37 \mathrm{oC}$. Yeast and mold were enumerated by a surface spread plate technique using potato dextrose agar (HiMedia - India) plates in triplicate. Plates were incubated at $25 \mathrm{oC}$ for $5 \mathrm{~d}$. Plates were incubated at $25 \mathrm{oC}$ for 5 days and the colonies were counted.

\section{Statistical analysis}

Significant differences between the results were calculated by analysis of variance (ANOVA) with the help of SAS software. Results were expressed as mean $\pm \mathrm{SD}$. Values were the average of triplicate experiments. Nonparametirc tests were performed to determine the statistical difference of the sensory data, and where appropriate, T-tests were performed for comparison of two means. Differences at $p<0.05$ was considered statistically significant for all analyses.

\section{RESULTS AND DISCUSSION}

The present study was carried out to investigate the possibility of producing novel synbiotic beverage by incorporating prebiotic microorganism L. casei $431^{\circledR}$ into carrot juice and fermented for different time intervals $(0$, 2 and $4 \mathrm{~h}$ ) at $37 \mathrm{oC}$. The optimum sensory 
attributes were determined based on sensory evaluation (Table 01) and overall acceptability was highest in the product fermented at $2 \mathrm{~h}$ time of fermentation.

Lactobacillus bacteria used in this study $L$. casei $431^{\circledR}$ is a novel bacterial strain developed by Chro-hansen, Denmark. The research carried out by CHR-HENSEN in Denmark indicated a probiotic bacteria $L$. casei $431^{\circledR}$ survive in the low acid juices up to at least 8 weeks. $L$ casei $431^{\circledR}$ incorporated juice has been designed to give the best results in many types of healthy fruit juices from citrus to apples, pears, berries and coconuts (www.chr-hansen.com). L.casei $431{ }^{\circledR}$ is proven to beneficially enhance the body natural defense which may increase protection and reduce risk of infections (Rizzardini et al., 2012).

The international standards describe that the probiotic products should be contained minimum of 108 viable probiotic bacteria per $\mathrm{mL}$ of the product at the time of consumption for health and functional claiming (Samona and Robinson, 1991). The beverage has reached to around 108 viable probiotic bacteria per $\mathrm{mL}$ of the product at the end of the 7 th week (47 days). Therefore, this beverage could be considered as a heath drink if consumed at 6 weeks of cold storage at $5 \pm 1{ }^{\circ} \mathrm{C}$ (Table 01). Similar research was undertaken to determine the suitability of cabbage as a raw material for production of probiotic cabbage juice by lactic acid bacteria (Lactobacillus plantarum, Lactobacillus casei, and Lactobacillus delbrueckii. Some researchers have viewed that several factors may affect the survival of lactic acid bacterial

Table 01: Descriptive analysis of the fermented product by semi trained panelists

\begin{tabular}{ccccc}
\hline Fermentation time $(\mathrm{h})$ & Taste & Odor & Acidity flavor & Overall acceptability \\
\hline 0 & $49.05 \mathrm{a}$ & $51.18 \mathrm{ab}$ & $45.50 \mathrm{a}$ & $48.13 \mathrm{a}$ \\
2 & $59.83 \mathrm{a}$ & $56.25 \mathrm{~b}$ & $50.16 \mathrm{~b}$ & $66.35 \mathrm{~b}$ \\
4 & $27.61 \mathrm{~b}$ & $29.06 \mathrm{c}$ & $40.83 \mathrm{c}$ & $22.01 \mathrm{c}$ \\
\hline
\end{tabular}

Kruskal Wallis test for the ranking of the beverage with different fermentation time strain, inoculation level incubation temperature, $\mathrm{pH}$ growth promoters, inhibitors, presence of hydrogen peroxide and oxygen concentration of metabolites, buffering capacity of the media, storage temperature and availability of nutrients. In this study, even after 6 weeks of storage at $5 \pm 1^{\circ} \mathrm{C}, \quad$ L. casei capable of surviving in the fermented carrot juice at $\mathrm{pH} 5.0$. In the present study, the levels of $\mathrm{pH}$ was maintained for the survival of bacteria in the product.

Lactobacillus casei $431{ }^{\circledR}$ is a homofermentative bacteria which can only produce lactic acid by fermentating carbohydrates such as sucrose, fructose, glucose and prebiotics. The optimum $\mathrm{pH}$ for growth of L. casei $431^{\circledR}$ is 5.5 (Ch. Hansen A/S, 2008). Therefore, the $\mathrm{pH}$ of carrot juice has reduced by adding citric acid. There were significant reduction of $\mathrm{pH}$ (5.98 to 5.01) and increase of titratable acidity (1.73- 5.03 $\times 10-3 \mathrm{~mol} / \mathrm{L}$ ) in the beverage during storage up to 6 weeks (Table 02).

In this research, lactic acid fermentation of the beverage has been limited by storing the beverage under refrigerated conditions $(5 \pm$ $1^{\circ} \mathrm{C}$ ). Nighswonger et al., (1996) revealed that there was a slight fermentative activity by the probiotic organism even at $4^{\circ} \mathrm{C}$.

The $\%$ of reducing sugar, sucrose and total sugars significantly reduced with storage and least was observed at the 6 weeks of duration. Sugar consumption of L. casei $431^{\circledR}$ has been correlate with the lactic acid accumulation in the beverage (Hardberg et al., 2008). Therefore, sucrose is added at the time of preparing the beverage for the purpose of safe guarding prebiotics available in the beverage. 
Table 02: Changes in physico-chemical characteristics of the beverage during storage

\begin{tabular}{ccccccccc}
\hline $\begin{array}{c}\text { Time } \\
\text { Interval }\end{array}$ & $\mathrm{pH}$ & $\begin{array}{c}\text { Titratable Acidity } \\
(10-3 \mathrm{~mol} / \mathrm{L})\end{array}$ & oBrix & $\begin{array}{c}\text { Reducing } \\
\text { Sugar }(\%)\end{array}$ & $\begin{array}{c}\text { Sucrose } \\
(\%)\end{array}$ & $\begin{array}{c}\text { Total } \\
\text { Sugar } \\
(\%)\end{array}$ & $\begin{array}{c}\text { Total crude } \\
\text { fiber (\%) }\end{array}$ & $\begin{array}{c}\text { Radical } \\
\text { scavenging } \\
\text { activity (\%) }\end{array}$ \\
\hline 0 & $5.98 \mathrm{a}$ & $1.73 \mathrm{a}$ & $12.00 \mathrm{a}$ & $0.472 \mathrm{a}$ & $5.65 \mathrm{a}$ & $6.42 \mathrm{a}$ & $1.021 \mathrm{a}$ & $41.40 \mathrm{a}$ \\
1 & $5.88 \mathrm{~b}$ & $2.23 \mathrm{~b}$ & $12.00 \mathrm{a}$ & $0.455 \mathrm{~b}$ & $5.57 \mathrm{~b}$ & $6.32 \mathrm{~b}$ & $1.020 \mathrm{a}$ & $39.64 \mathrm{~b}$ \\
2 & $5.67 \mathrm{c}$ & $2.53 \mathrm{c}$ & $12.00 \mathrm{a}$ & $0.439 \mathrm{c}$ & $5.47 \mathrm{c}$ & $6.20 \mathrm{c}$ & $1.018 \mathrm{~b}$ & $39.44 \mathrm{~b}$ \\
3 & $5.44 \mathrm{~d}$ & $3.47 \mathrm{~d}$ & $12.00 \mathrm{a}$ & $0.436 \mathrm{~d}$ & $5.31 \mathrm{~d}$ & $6.02 \mathrm{~d}$ & $1.017 \mathrm{a}$ & $39.15 \mathrm{c}$ \\
4 & $5.37 \mathrm{e}$ & $3.87 \mathrm{e}$ & $11.50 \mathrm{~b}$ & $0.436 \mathrm{e}$ & $5.30 \mathrm{e}$ & $5.99 \mathrm{e}$ & $1.016 \mathrm{a}$ & $38.4 \mathrm{~d}$ \\
5 & $5.22 \mathrm{f}$ & $4.33 \mathrm{f}$ & $11.50 \mathrm{~b}$ & $0.416 \mathrm{f}$ & $5.21 \mathrm{f}$ & $5.90 \mathrm{f}$ & $1.013 \mathrm{~b}$ & $38.34 \mathrm{~d}$ \\
6 & $5.01 \mathrm{~g}$ & $5.03 \mathrm{~g}$ & $11.50 \mathrm{~b}$ & $0.411 \mathrm{~g}$ & $5.20 \mathrm{~g}$ & $5.88 \mathrm{~g}$ & $1.011 \mathrm{~b}$ & $36.91 \mathrm{e}$ \\
\hline
\end{tabular}

Means followed by different superscript as letters (a, b, c, d, e, f and g) in a column differ significantly at $5 \%$ level

The probiotic organism has metabolized more reducing and non reducing sugars due to its high concentration in the beverage. Some recent researches have revealed that metabolizing of fructo-oligosaccharides and inulin is low if the beverage has not sufficient level of sugars like glucose, fructose and sucrose. Therefore, adding sugar is important to this type of beverages where probiotic organism only depend on native prebiotics in the beverage.

oBrix value of the beverage has slightly decreased with storage (Table 02) which could be due to the chemical interactions taking place among the organic constituents of the beverage (Ghorai and Khurdiya, 1998). Especially, reduction of total sugar content is the main reason for the reduction of the ${ }^{\circ}$ Brix value because of the fermentation of $L$. casei within the storage. Apart from that, oxidation of vitamin $\mathrm{C}$ also may be a reason for the reduced ${ }^{\circ}$ Brix value (Simsek, 2011).

A few studies on the antioxidant properties of vegetables have suggested that vegetables are excellent dietary sources of natural antioxidants. Vegetables, including broccoli, carrot, potato, and tomato are rich in phenolic compounds and one of the important characteristics of polyphenolic compounds is their antioxidant capacity. The antioxidant activity of carrot juice was measured with respect to the radical scavenging activity of the beverage. The juice which was inoculated with $L$. case $i$ exhibited value of DPPH free radical activity about $40.41 \%$. The free radical activity was decreased by $5 \%$ during 6 weeks period of storage at 5 $\pm 1^{\circ} \mathrm{C}$.

Table 03: Results of proximate analysis of the carrot beverage

\begin{tabular}{lc}
\hline \multicolumn{1}{c}{ Component } & Amount $(\mathrm{g} / 100 \mathrm{~g}$ wet basis $)$ \\
\hline Moisture & $88.35 \pm 0.15$ \\
Dry matter & $11.65 \pm 0.05$ \\
N Free extract & $9.13 \pm 0.12$ \\
Ash & $1.56 \pm 0.01$ \\
crude fibre & $1.10 \pm 0.01$ \\
Crude Protein & $0.81 \pm 0.02$ \\
\hline
\end{tabular}


$\beta$ carotene and ascorbic acid content of this synbiotic carrot beverage is high and both vitamins are light sensitive. Thus, Oxidation of $\beta$ carotene and vitamin $C$ could be the main cause to the reduction of free radical scavenging activity.

Raw and fresh carrot contains $2.8 \mathrm{~g} / 100 \mathrm{~g}$ of dietary fiber by nature. After $2 \mathrm{~h}$ fermentation the beverage resulted $1.02 \%$ of crude fiber. It is well known that the majority of crude fiber are cellulose, hemicelluloses and lignin. Besides those fibers Inulin and Fructo-oligosaccharides are prebiotics belongs to the category of fibers (Qiang et al., 2009)

L. casei 431 is a probiotic which can metabolize above prebiotics and can live by using those prebiotics as substrates. To be a synbiotic beverage, the amount of inulin and fructooligosaccharids should be maintained until the consumption because there was no introducing of external prebiotics to the product. Both inulin and FOS are long chains made out of fructose and inulin is with a glucose molecule at the terminal of the structure Schaafsma and Slavin 2015.

According to the data there was no significant $(p<0.05)$ reduction of content of crude fiber within the storage period. It seems that prebiotics in the beverage have been preserved until the end of the shelf life due to high concentration of sugars in the product. Crude fiber content was high in this beverage when compared with other ready to serve (RTS) beverages, and with low levels of protein. Based on existing standards and from a health view-point, it is very important that probiotic strain retain their viability and functional activity throughout the shelf life of the product. The presence of plantbased ingredients may improve the growth of probiotic cultures like $L$. casei in tomato juice, peanut milk, soy milk, carrot and cabbage like juices (Nadal et al., 2010).

However, little is known about the stability of probiotics in non-dairy products. One of the main disadvantages of using fermented products as carriers of probiotics is the formations of end-products with fermentation, but $L$. casei produce only lactic acid as an end product with fermentation.

The main factors for loss of viability of probiotic organisms are decreasing the $\mathrm{pH}$ of the medium and accumulation of organic acid as a result of growth and fermentation of L. casei.

Lactic acid bacteria not only improve health when product consumed, but they can also play a protective role against pathogens in the product itself during storage by competing with pathogens for nutrients, producing organic acids and bacteriocins (biopresevation). Biopreservation is the extension of storage life and enhancing of safety of foods using the natural or controlled microflora and/or their antimicrobial products (Rodgers, 2001).

Although a slight acidification of the beverage was detected by the sensory panels, the beverage was acceptable for a period of 6 weeks at $5 \pm$ $1^{\circ} \mathrm{C}$.

\section{CONCLUSION}

Based on the results of this study, it can be concluded that carrot juice is a good substrate for the growth of Lactobascillus casei $431^{\circledR}$, and can be utilized in the production of fermented ( 2 h) beverage.

The amount of probiotic organism was within the standards (10-8- 10-10 CFU/ mL) until the end of the 6 weeks. This research has demonstrated that a good quality synbiotic beverage could be achieved with acceptable sensory characteristics for 6 weeks of storage under refrigerated $\left(5 \pm 1^{\circ} \mathrm{C}\right)$ conditions.

\section{ACKNOWLEDGEMENTS}

Authors gratefully acknowledged Mr Nuwan 
Ilanka, J L Morison Son \& Jones (Ceylon) PLC Grant, The Open University of Sri Lanka for for providing cultures and Faculty Research financial assistance.

\section{REFERENCES}

A-O-A-C (2000) Official Methods of Analysis. Association of Official Analytical Chemists 920.1839 (b) Sugars (Reducing) in Honey. $17^{\text {th }}$ edition. Washington D.C.

Barreteau H., Delattre C. and Michaud P. (2006). Production of Oligosaccharides as Promising New Food Additive Generation Food Technol. Biotechnology. 44 (3), pp 323-333.

De Man, J.D., Rogosa, M., and Sharpe, M.E. (1960). A Medium for the Cultivation of Lactobacilli. Journal of Applied Bacteriology 23, pp 130-135. http://dx.doi.org/10.1111/j.1365-2672.1960. tb00188.x

Evangelista S. R., Ghiselli G. andFilhoF.M.(2012). Development of a Soy-Based Sybiotic Beverage. Food and Nutrition Sciences, Vol. 3, No. 8. http://dx.doi.org/10.4236/fns.2012.38148

Ghorai K. and Khurdiya D.S. (1998). Storage of heat processed kinnow, mandarin juice. Journal of Food Science and Technology 35(5), pp 422-424.

Gibson G. R, Ottaway P. B. and Rastal R. A. (2000). Prebiotics. Chandos Publishing (Oxford) Ltd, Oxford, England: pp 1-20.

Grajek W., Olejnik A. and Sip A. (2005). Probiotics, prebiotics and antioxidants as functional foods, Acta Biochimica Polonica, Vol. 52, pp 665-671.

Hedberg M, Hasslof P, Sjöström I, Twetman S, Stecksen-Blicks C. Sugar fermentation in probiotic bacteria - an in vitro study. Oral Microbiol Immunol 2008;23: pp 482-485. http://dx.doi. org/10.1111/j.1399-302X.2008.00457.X

Nadal E., Barbera E., Lopez J. and Álvarez J (2010). Food formulation to increase probiotic bacteria action or population. In: WATSON, R.R. and PREEDY, V.C. eds. Bio active foods in promoting health: Probiotics and Prebiotics. Academic Press, Elsevier, London, UK, 342.

Nazzaro F., Fratianni F., Sada A. and Orlando P. (2008). Synbiotic potential of carrot juice supplemented with Lactobacillus spp. and inulin or fructooligosaccharides. Journal of the Science of Food and Agriculture Vol 88, No 13, pp 2271-2276. http://dx.doi.org/10.1002/ jsfa.3343

Nighswonger B.D, Brashears M.M. and Gilliland S.E. (1996). Viability of Lactobacillus acidophilus and Lactobacillus casei in fermented milk products during refrigerated storage. Journal of Dairy Science, Vol. 79, No 2, pp 212-219. http://dx.doi.org/10.3168/jds.S00220302(96)76353-1

Qiang X, YongLie C. and QianBing W. (2009). Health benefit application of functional oligosaccharides.482 CarbohydrPolym.Vol 77: pp 435-441 
Rizzardini G., Eskesen D., Calder P.C., Capetti A.J., Jespersen L. and Clerici M. (2012). Evaluation of the immune benefits of two probiotic strains Bifidobacterium animalis ssp. lactis, BB-12 ${ }^{\circledR}$ and Lactobacillus paracasei ssp. paracasei, L. casei $431^{\circledR}$ in an influenza vaccination model: a randomised, double-blind, placebo-controlled study British Journal of Nutrition. Vol. 107, pp 876-884. http://dx.doi.org/10.1017/s000711451100420x

Rodgers S. (2001). Preserving non-fermented refrigerated foods with microbial cultures-a review. Trends in Food Science \& Technology, Vol. 12, No 8, pp 276-284. http://dx.doi.org/10.1016/ S0924-2244(01)00093-0

Samona A. and Robinson R.K. (1991). Enumeration of bifidobacteria in dairy products. International Journal of Dairy Technology, Vol. 44, No. 3, pp 64-66. http://dx.doi. org/10.1111/j.1471-0307.1991.tb00639.x

Schaafsma G. and Slavin J.L. (2015). Significance of inulin fructans in the human diet. Comprehensive Reviews in Food Science and Food Safety, Vol. 14, pp 37-47.

Sharma K. D., Karki S., Thakur N.S and Attri S. (2012). Chemical composition, functional properties and processing of carrot. A Review. Journal of Food Science and Technology, Vol. 49, pp 22. http://dx.doi.org/10.1111/1541-4337.12119

Simsek M., (2011). A Study on Selection and Identification of Table Fig Types in East Edge of Firat River. Asian Journal of Animal and Veterinary Advances Vol.6, pp 265-273. http:// dx.doi.org/10.3923/ajava.2011.265.273

Sousa V. M. C., Santos E.F. and Sgarbieri V.C. (2011). The Importance of Prebiotics in Functional Foods and Clinical Practice, Food and Nutrition Sciences Vol. 2, No. 2. http://dx.doi. org/10.4236/fns.2011.22019

Stone H. and Sidel J. L. (1993). Sensory Evaluation Practices, $2^{\text {nd }}$ edition. Academic Press: San Diego. 